\title{
Britain's resources of coal and spent uranium fuel
}

\section{Robert Olby*}

THE United Kingdom is of ten described as a favoured nation in an increasingly energy-hungry world - possessing riches of coal, and also North Sea oil and gas and an abundance of spent fuel from nuclear reactors. Before the OPEC oil price rise of 1973 it was generally accepted that dependence on coal should continue to decline in favour of oil and nuclear power. The imposition of a fuel tax on oil in 1961 marked an attempt to slow down the rate of oil substitution, but nevertheless between 1959 and 1973 oil consumption more than doubled, and by 1973, 3 per cent of total primary energy was supplied by nuclear power. The action of OPEC not only strengthened the argument for nuclear power based on its contribution to national security but within the National Coal Board it brought to the fore the already active concern to reassess the future of coal.

In the board's Plan for Coal (1974), investment of $£ 1,400$ million over the following decade was proposed, $£ 8$ million, of which was to be spent on an intensified programme of exploration to decide on the best sites for future development. Three years later, this expansionist mood became apparent to all with the announcement of the board's revised estimates of the United Kingdom's "physically recoverable" reserves. To a British Association audience the then-chief geologist to the board, A. Michael Clarke, declared that economics and a lack of sufficient physically recoverable reserves of coal were not the sole determinants of the choice between coal and nuclear future bulk energy supplies for Britain and Europe. Just because the era of cheap oil had taken an unnecessary slice from the life of UK coal reserves, it was not the case that in the long-term we lacked adequate reserves. To go nuclear, he declared, was not therefore inevitable.

The United Kingdom's reserves, which the World Energy Conference Survey of Energy Resources for the reference year 1975 (published 1977) had shown as $3.887 \times 10^{9}$ tonnes, were now claimed by the board to be $45 \times 10^{9}$ tonnes. Small wonder that this apparent dramatic change caused adverse comment from the Institution of Geological Sciences (IGS), letters in The Times and a tart editorial in Nature.

In 1975 Sir John Hill, chairman of the Atomic Energy Authority, drew attention to the potential energy source available in spent uranium fuel. With the fast reactor, he claimed, Britain's spent fuel could yield

-The University of Leeds Department of Philosophy, Leeds LS 9JT, UK

as much as $50 \times 10^{9}$ tonnes of coal, more, he declared than Britain's total coal reserves which, according to the National Coal Board in 1969 were about $20 \times 10^{9}$ tonnes. In 1976 Sir John's colleague T.N. Marsham gave the more conservative coal equivalent of stored spent fuel as $20 \times 10^{9}$ tonnes, which Sir John later doubled to $40 \times 10^{9}$ tonnes a year. Between these two values came the Coal Board's new estimate of Britain's coal reserves at a little more than twice T.N. Marsham's figure.

\begin{abstract}
During the 1970s estimates of the United Kingdom's reserves of coal and spent fuel from nuclear reactors, provided by the National Coal Board and Atomic Energy Authority respectively, have tended to steadily increase. It is tempting to infer a connection between these estimates and the efforts of the NCB and AEA to promote their claims on government finance, by each predicting as long-lived a future secure energy source as its rival. This article follows the history of the various estimates and attempts to assess their credibility.
\end{abstract}

\section{Dwindling resource}

Although the long-term future of coal as the United Kingdom's chief energy source was a matter for concern after the Second World War, the subject had long been debated. In 1789 John Williams discussed the "limited quantity of coal in Britain" in his book Natural History of the Mineral Kingdom, and in the 1810 edition edited by James Miller, Macnab's 1792 estimate of 360 years' supply was given. This figure related only to the coalfields of Northumberland and Durham and the extraction rates of that period. In the nineteenth century the Oxford geologist, William Buckland, urged upon the parliamentary committees of 1830 and 1835 the need to conserve coal. In 1830 the old sea-coal tax had been abolished, but twelve years later Sir Robert Peel put a tariff on all exported coal.

The subject of coal resources came before Parliament once again when the Commercial Treaty with France was debated in 1860. According to Article 11, no duty was to be levied upon coal exported to France and other nations with whom the United Kingdom was at peace. It was the discussion of this treaty which caused Edward Hull, member of the Geological Survey, to write The Coalfields of Britain (1860) in which he took a sanguine view. Introducing the mining limit of a depth of 4,000 feet he reckoned England and Wales had just under $59 \times 10^{9}$ tons, enough for about a thousand years. In the second edition of 1862 Hull included the Scottish coalfields which raised his estimate to $79.8 \times 10^{9}$ tons. Hull recoiled from the implications of continuing indefinitely the rate of expansion of coal extraction of the first half of that century ( 800 per cent) Such a drain on the country's "life-blood" would exhaust its resources by AD 2034. On the other hand, if, as Edward Hull believed, the coal industry would be incapable of raising more than 100 million tons per annum, the nation still had eight centuries of supplies. Meanwhile he looked to science to show how we could win energy from "the light and heat that is everywhere around us". Appealing to God's provi- dential character he assured his readers: "nor can we suppose that any part of the Creator's universe has been regulated on so short-sighted a plan, that it shall become disorganized because some of the elements necessary to its economy have failed"'

The optimism of Edward Hull was matched by the stern realism of the economist and statistician, W. Stanley Jevons. In his celebrated work, The Coal Question (1865) he calculated the duration of British coal on the basis of Hull's estimate of reserves and the extrapolation into the future of the historic trend in coal consumption, which had been $3.4 \%$ per annum over the decade 1851-61. His conclusion was that: "Rather more than a century of our present progress would exhaust our mines to the depth of 4,000 feet . . ." Jevons was widely misunderstood as predicting exhaustion around the year 1975 , whereas he was really trying to show that the nation's industrial expansion could not continue for long at the rate then current. Whilst there was still plentiful cheap coal attempts should be made to reduce the national debt, introduce a general system of education, and impose a far more general restriction on child labour. Such tasks would be more difficult to achieve when other countries reached and surpassed the output of Britain's mines, becoming more competitive in world markets (by 1967 US pithead prices were half those of Britain). Although Jevons foresaw this situation he could not, as a free-trader, recommend the imposition of an export tariff on coal. Therefore it was clear to him that the cost of coal extraction was a decisive factor in determining the 
proportion of Britain's total coal resources which would be extracted. In the future we might, indeed, be able to mine coal at greater depths than at present, but only if the price was competitive in world markets. There was no question of the physical exhaustion of our coalfields - " "though we may some day have to pay dear for fuel; it will never be positively wanting"', he explained in the second edition of The Coal Question. Here Jevons was expressing what later became a major feature of the distinction between reserves and resources, the history of which is recounted below.

Jevons drove his point home by a demonstration of the unique character of coal. In a remarkable chapter on subtitutes in the third edition of his book (1906), he discounted sunlight, peat, hot springs, water and wind power, the tides, petroleum, hydroelectricity and hydrogen produced by the electrolysis of water. $\mathrm{He}$ found it absurd to picture the 7,308 horses or 1,000 large windmills which would be required to power a modern factory like the great Dowlais ironworks, and he pointed to the fallacy of considering electricity as a source of self-creating power. The chief targets of this critique were the optimists, Dionysius Lardner, Charles Babbage and Edward Hull.

Sir John Herschel applauded Jevons. "Such a work as yours", he wrote, "has long been wanted to dissipate completely the delusion which so large a majority of our countrymen labour under, of the 'inexhaustibility of our mineral resources' etc. and the 'probability amounting to certainty' that science will ere long put us in possession of a substitute for coal . . . after this let no man plead ignorance and say 'who would have thought it'." Herschel went on to describe his favourite notion of using the tides by running pipes under the sea to a distance of 1,000 feet around 1,570 miles of coastline from Berwick-on-Tweed to the Solway Firth. With a 6-foot tidal fluctuation he reckoned this vast construction would supply only one million tons of coal equivalent - one fifth of London's annual consumption or enough to keep ten Great Easterns constantly under steam.

By the summer of 1866 , Jevons had become a newspaper celebrity. Gladstone wrote to him, J.S. Mill quoted him and Queen Victoria appointed a Royal Commission on coal chaired by the Duke of Argyll. In its report five years later, this commission estimated the amount of coal which "may reasonably be expected to be available for use" as $90.2 \times 10^{9}$ tons in ascertained coalfields, plus a possible $56.3 \times 10^{9}$ tons elsewhere. The resulting total recoverable resource figure of $\sim 146 \times 10^{9}$ tons within a depth of 4,000 feet appears to have been accepted.

The commissioners were sceptical of making projections of future demand based on historic trends; they doubted that Britain's coal would ever be absolutely exhausted, but the country would lose its advantageous position in regard to coal supplies, coal imports would become the rule rather than the exception. Ominously the report concluded with the sentence: "But it may well be doubted whether the manufacturing supremacy of this kingdom can be maintained after the importation of coal has become a necessity."' These views were not substantially revised by the Royal Commission of 1901 , nor by anyone else.

Like their 1871 predecessors, the 1901 commissioners misunderstood Jevons. They arrived at an estimate of total available coal to 4,000 feet of nearly $142 \times 10^{9}$ tons, $40.7 \times 10^{9}$ tons being in "unproved" coalfields. The approximate agreement between the two commissions' estimates, despite the quantity of coal extracted in the interval, was due in Jevons' son, Herbert's, opinion "to the well known law that a number of unbiassed errors tend to cancel one another'". Nevertheless it consolidated a growing consensus that Britain had at least $140 \times 10^{9}$ tons of which the proportion in "proved" coalfields was increasing due to continued exploration. Conversely, the consensus was developing that as more of the best and most accessible coal was removed, the remainder would be increasingly difficult and expensive to mine. Therefore, the 1901 commission declared, the rate of increase of extraction, "will soon be checked by natural causes" so that there was "no present necessity to restrict artificially the export of coal in order to conserve it for our home supply"'.

In the inter-war period, the coal industry laboured under many difficulties, the chief of which was falling demand. By the time of nationalization in 1947 it was in a parlous state, having suffered from many years of financial stringency and lack of investment. Despite extensive mecha- nization output had not grown as it had in continental mines. This was chiefly due to the winding and undulating character of the underground lay-outs ("in-seam mining") in Britain in contrast to the straight roads which were driven through the strata on the continent ("horizon mining"). The latter layout was easier to mechanize throughout. In Britain the work of the coal-filler at the end of the conveyor belt remained unmechanized and constituted the bottle neck in the system until the 1960 s.

Although Britain did not suffer so acutely after the Second World War as other European countries from coal shortages, demand was depressed by the system of allocation to consumers and there were frequent electricity cuts. Even allowing for the growth of the oil industry with Marshall Aid a long-term reorganization of the coal industry would be required to expand production. Such anticipated expansion did continue until 1958 when the threat of cheap oil began to bite into coal's traditional markets confounding the prophets of its future demand.

In such difficult circumstances mines were being closed at a rate of 40 a year, and the economically workable reserves were written off (depleted) at an alarming rate. The result is seen in the figure below.

The value of $3.87 \times 10^{9}$ tonnes appeared in the 1974 World Energy Conference Survey of Energy Resources alongside a figure for total coal reserves of $99 \times 10^{9}$ tonnes and almost $163 \times 10^{9}$ tonnes for total resources. It did not escape the notice of the conference report that the United Kingdom's recovery percentage was thus only 4 per cent in contrast to West Germany's 40 per cent. On his return from

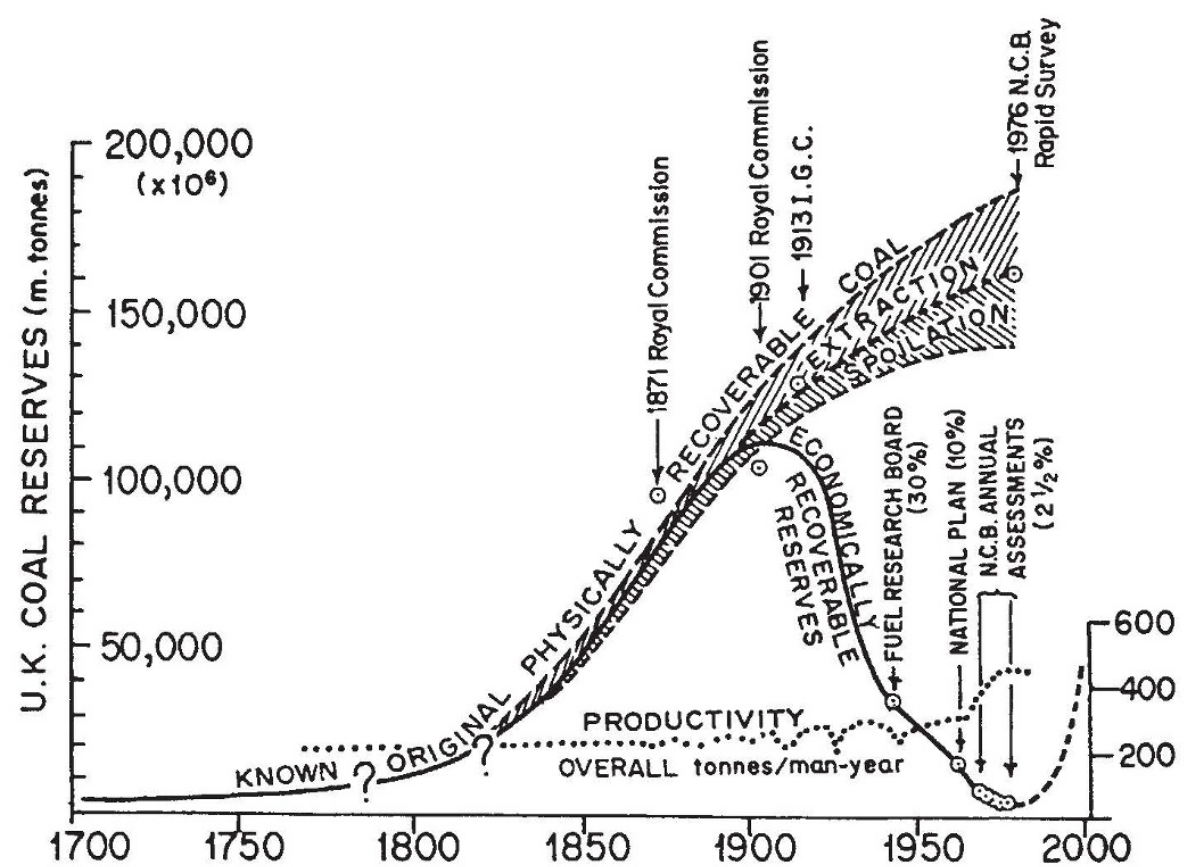

Historic changes in estimates of UK coal reserves and productivity (tonnes per man-year). Adapted from A.M. Clarke in Australia's Mineral Sources (eds G.M. Philip \& K.L. Williams, Sidney, 1978). 
the conference Leslie Grainger, the National Coal Board's Member for Science, pointed out the absurdity of these data to the board.

A hint of what had happened can be found in the World Energy Conference Survey for reference year 1975 . Although total reserves were now nearly $101 \times 10^{9}$ tonnes, economically recoverable reserves were still only $3.887 \times 10^{9}$ tonnes. From a footnote we learn that this figure concerned reserves at existing collieries and opencast sites (what are usually described as "operating reserves"). A second footnote tells us that the National Coal Board's "alternative" estimate for economically recoverable reserves (not restricted to those with access from existing mines and by local marginal costs) was $45 \times 10^{9}$ tonnes.

\section{Resource terminology}

Was this confusion merely a product of the semantics of resource estimates or of some deeper issues? Clearly there is still not a consensus over the former if only because different resources tend to be suited to different terminological rules and the needs of the smaller commercial mining companies are not the same as those of a nationalized industry. The roots of a precise terminology can be seen in Herbert Hoover's little classic, The Principles of Mining (1909), where the tripartite division of mineral ores into proved, probable and prospective was recommended. Four years later the staff of the Canadian Geological Survey, in their task of assessing world coal resources for the twelfth International Geological Congress, asked for returns to be classified into two groups (above and below 4,000 foot depth) and these to be subdivided into actual, probable and possible. These terms, or their equivalents, were used by mining engineers and mining geologists in the preparation of expert advise on the likely profitability of mining ventures. They expressed the level of confidence to be placed on the extent and availability of the resources in the mine, and were intended to protect the investor from exposure to fraudulent claims made on behalf of unsound commercial ventures. Therefore they referred to existing technical and economic conditions.

During the Second World War the United States government, concerned about their mineral resources, held Senate hearings on the subject at which the Bureau of Mines and the Geological Survey (USBM/USGS) proposed a new tripartite definition of reserves as measured, indicated, and inferred, each division representing defined levels of reliability, the highest being the \pm 20 per cent of measured reserves. The long-term needs of such national assessments led S.G. Lasky in 1949 to make an important distinction between reserves and resources, two terms hitherto used interchangeably. Whereas reserves (measured, indicated and inferred) were known to exist and had "aspects of usability within a practical limit of time and within a specified set of economic and technologic conditions", resources comprised "all materials in the ground, discovered or undiscovered, usable at present or not, . . . considered within the context of all factors ... that may influence its conversion into a 'reserve', and .... that enter into prediction or opinion as to possible future usability". This distinction was recognized in Blondel and Lasky's 1956 equation:

Resources $=$ Reserves

$$
\begin{aligned}
& \text { + Marginal resources } \\
& + \text { Submarginal resources } \\
& + \text { Latent resources }
\end{aligned}
$$

It has become increasingly recognized internationally, and has influenced the World Energy Conference classification whose 1974 Survey definitions were:

Total resources: "The total quantities available in the earth that may be successfully exploited and used by man within the foreseeable future."

- Total known reserves-in-place: "The corresponding fraction of resources that have been carefully measured and assessed as being exploitable in a particular nation or region under present local economic conditions using available technology."

Recoverable reserves: "That fraction of reserves-in-place that can be recovered under the above economic and technical limits."

Additional resources: "All other classifications with a lower degree of geologic certainty as to their existence than those indicated as known."

Of this last category the 1980 Survey remarked that they:

embrace all resources, in addition to proved reserves, that are of at least foreseeable economic interest. The estimates provided for additional resources reflect, if not certainty about the existence of the entire quantities reported, at least a reasonable level of confidence. Resources whose existence is entirely speculative are not included.

What, then, is the meaning to be attached to the United Kingdom's 1977 figures of (in tonnes):

Total reserves

$100 \times 10^{9}$

Economically recoverable 45 reserves

Additional resources

Total resources

The National Coal Board maintains that within $1.2 \mathrm{~km}$ depth and in seams over 60 $\mathrm{cm}$ thick there are about $190 \times 10^{9}$ tonnes of coal, of which some $100 \times 10^{9}$ tonnes are well ascertained but no figure has been given for the confidence level. These estimates are in line with the general trend of the Royal Commissions of 1871 and 1901. The figure of $45 \times 10^{9}$ tonnes for economically recoverable reserves shows the recognition of the fact that recovery of what is known to be in the ground has fallen from the nineteenth-century level of between 70 and 80 per cent to about 50 per cent. This fall, due to both economic factors and to mechanization, could in Clarke's opinion be reversed under high oil prices and a vigorous programme of coal exploration. Over the next decade $\mathrm{K}$. Moses thought the figure for economically recoverable reserves might well rise to 50 or even $60 \times 10^{9}$ tonnes. Clarke suggested the possibility of returning to the older recovery percentages which would push the figure up to $90 \times 10^{9}$ tonnes. Before the oil price rise of 1973, George Armstrong, then chief geologist to the National Coal Board assessed the current recovery of reserves at about 25 per cent, but he clearly anticipated a major change in the industry given increased investment. With capital, he explained, "access could be made to the best seams in the vast extentions of our existing coalfields", and we should see "for the first time since the latter part of the nineteenth century . . . an increase in the reserves of coal in Britain which can be considered as economically workable"'. He never denied the $200 \times 10^{9}$ tonnes total UK resources but considered this figure of "only academic interest" and "grossly erroneous as an estimate of economically workable reserves". It was right that under stricter rules of resource estimation the old UK figures, like the early American ones, should have been reduced. It was not that some of this coal had never existed, or had vanished since 1900 , but that the onus was put on the coal industry and the nation to support the exploratory research and technical development needed to bring more and more of the resources into the reserves, and thus afford a clearer picture of the future potential of our coalfields.

Nevertheless, it should be stated that there is not yet a consensus between geologists within and without the coal industry as to how much of the coal in the UK's abandoned fields remain accessible for future extraction.

\section{Towards atomic power}

The recognition of the industrial advantage to be reaped by the nation which leads the world in the exploitation of a new source of power lay behind the public and governmental enthusiasm for exploiting the atom. Radioactivity was considered as a possible novel source of power long ago in the Times Literary Supplement for 17 July 1903. Radium was considered amongst those "gigantic possibilities, which are not probabilities at all yet ...". Frederick Soddy, who had "ghosted" the article, pictured how much energy radium would yield if its rate of disintegration could be speeded up. Rutherford, the article reported, "has calculated from his own experiments and those of Curie that the energy stored up in one gramme of radium is sufficient to raise 500 tons a mile high. An ounce would therefore suffice to drive a 50 horsepower motor car at the rate of 30 miles per hour round the world"'. If it could be achieved with radium if could be achieved with uranium and thorium. "Our 
fathers busied themselves with speculating what would become of us when the world's supply of coal was exhausted. A single step of science is needed for that problem to be answered in a manner beyond the dreams even of the scientific novelist."

We all know that these prophetic words were fulfilled (for uranium not radium) when in 1939 Lise Meitner and Otto Frisch interpreted the experimental results of nuclear fission; and Halban, Joliot and Kowarski, Fermi and others discussed the possibility that it might be accompanied by a chain reaction. That year was not only the annus mirabilis of nuclear fission, it also marked the first attempt to calculate the potential electricity output of a power station run from a "uranium boiler". $S$. Flügge calculated in Die Naturwissenschaften that complete fission of one cubic metre of uranium oxide powder would yield $7 \times 10^{10} \mathrm{kWh}$ of electricity, sufficient to replace the entire output of Germany's power stations running on middle-German brown coal for 11 years.

Comparisons such as Flugge's have been made repeatedly since 1939 in order to give some conception of the contrast in the concentration of energy in fissionable fuels as compared with fossil fuels. Hitherto the largest yield from a nuclear transformation had been the $22.2 \mathrm{MeV}$ from the conversion of lithium $\left({ }^{6} \mathrm{Li}\right)$ into alpha particles $\left({ }^{4} \mathrm{He}\right)$. But when M.C. Henderson measured the energy yield from uranium in 1939 it was a staggering $175 \mathrm{meV}$ (theoretical value, $198 \mathrm{MeV}$ ). (The beta decay of radioactive fission products subsequent to fission of ${ }^{235} \mathrm{U}$ is $21 \mathrm{MeV}$, and has to be subtracted from the $198 \mathrm{MeV}$.) The table below illustrates the million-fold increase in yield per atom when we go from combustion to fission.

\begin{tabular}{lll}
\multicolumn{3}{c}{ Theoretical energy yields per atom } \\
${ }^{12} \mathrm{C}$ & Combusion & $4.17 \mathrm{ev}$ \\
${ }^{226} \mathrm{Ra}$ & Fission & $4.79 \mathrm{MeV}$ \\
${ }^{235} \mathrm{U}$ & Fission & $198 \mathrm{MeV}$
\end{tabular}

When we compare uranium and carbon weight for weight the ratio is approximately 3 million to one. But H.D. Smyth in his report on the Manhattan project considered what the fission/combustion ratio would be if by fission all the matter of the atom was converted into energy. The equation relating matter and energy $(e=$ $m C^{2}$ ), he wrote,

\footnotetext{
... shows that one kilogram $(2.2 \mathrm{lbs})$ of matter, if converted entirely into energy, would give 25 billion Kwh of energy. This is equal to the energy that would be generated by the total electric power industry in the United States (as of 1939) running for approximately two months. Compare this fantastic figure with the $85 \mathrm{Kwh}$ of heat energy which may be produced by burning an equal amount of coal.
}

Smyth knew then, as we know now, that less than 0.1 per cent of the matter in uranium can be converted into energy by fission (to be precise it is 0.091 per cent). His calculation showing a ratio of $3 \times 10^{9}$ to one was therefore knowingly a thousand-fold exaggeration. He also knew what Flügge did not know, namely that only 1 in 139 (usually stated as 1 in 140) of the atoms in uranium is readily fissionable with slow neutrons, that is, those of the isotope ${ }^{235} \mathrm{U}$.

As later experience showed, the utilization of uranium by Britain's Magnox reactors is about 0.5 per cent (of which ${ }^{235} \mathrm{U}$ contributes about 0.35 per cent and the rest comes from the isotopes of plutonium and other elements). Taking a very high grade uranium ore with $1 \%$ uranium content, one fifth of which is recovered in extraction, and comparing it with a secondgrade $_{-1}$ bituminous coal ( $50 \%$ carbon) and some $30 \%$ of stone chips and dust our 'from the ground' ratio for Magnox reactors would be:

$$
\frac{3 \times 10^{6}}{100 \times 200} \times \frac{1}{5} \times \frac{100}{35} \bumpeq 86.1
$$

Research carried out in the United States during the Second World War made uranium look much more attractive than the 21,000:1 ratio suggested, for the elements heavier than uranium, elements 93 and 94 in the Periodic Table, were discovered as products of neutron capture by the abundant isotope of uranium, ${ }^{238} \mathrm{U}$. By 1941, Glenn Seaborg and co-workers had isolated element 94 and called it plutonium, ${ }^{239} \mathrm{Pu}$. As expected from theoretical considerations it proved fissile together with ${ }^{240} \mathrm{Pu}$ and ${ }^{241} \mathrm{Pu}$ by both thermal and fast neutrons.

Estimates of world uranium supplies won a new significance in December 1951 when the US experimental breeder reactor (EBR 1) yielded electricity to the grid and it had been shown meanwhile that the number of atoms of the abundant ${ }^{238} \mathrm{U}$ converted to fissile ${ }^{239} \mathrm{Pu}$ exceeded the number of ${ }^{235} \mathrm{U}$ atoms fissioned. That meant that more fuel was 'bred' than was consumed.

The principle of the breeder reactor having been experimentally established, energy forecasters waxed confident about a world energy future based on uranium. Palmer Cosslet Putnam in his report to the US Atomic Energy Commission in 1953 included all low-grade sources of uranium in his calculation of recoverable world reserves at 25 million tonnes, with an energy yield of $1,716 Q$, one third of which - $575 Q$ - it would be economical to 'burn'. As he was contracted by the commission to estimate the maximum possible contribution which nuclear power could make, it is hardly surprising that this estimate of uranium reserves was wildly exaggerated. Today figures in the range 6.6 to $\mathbf{1 4 . 5}$ million tons have been dismissed as misleadingly fanciful. Total world reserves are still put at less than $\mathbf{2}$ million tons, plus additional resources of little above 1.5 million tons. When Hans Thirring reworked Putnam's uranium estimates in 1958 he neglected or rejected the one third utilization which Putnam made to allow for losses during recycling of the fuel in the breeder, with the result that Thirring's value for uranium reserves was $2,000 Q$. "The date of depletion of the energy capital of our Earth", he concluded in Energy for Man, "is therefore prolonged by at least a millenium ... Thus the consequence of Hahn's great discovery will free us from the fear that our energy resources will run out within quite a short period of history."

\section{US coal resources}

A more surprising aspect of Putnam's report was his reworking of the estimates of US coal resources. To the 1944 figure of $3,100 \times 10^{9}$ tonnes (total resources) he applied a series of correction factors which reduced it by nine tenths. As Schurr and Netschert have well said Putnam's resulting 3.1Q's worth of recoverable US coal reserves "is based on limiting criteria that have no consistent basis; some of them are wholly arbitrary and some of them have no relation to coal actually in stock".

Nuclear scientists have to their credit that they have in the past cautioned against the acceptance of wildly enthusiastic claims for nuclear power. Such euphoric remarks included the "pill-in-a-pail" suggestion made in the US Congress in 1946. All you needed to heat your house for a year, according to this idea, was a small pill of uranium in a pail of water. Other calculations suggested that a piece of uranium the size of an egg would propel the Queen Mary from New York to Europe and back, whilst other pundits claimed that one the size of a pea placed under the doorstep would suffice to heat a house for its entire lifetime.

At the end of the Second World War, experience with the Hanford reactors had shown that very little of the 0.7 per cent ${ }^{235} \mathrm{U}$ in the fuel was 'burnt' before 'poisoning' seriously reduced fission. This led Oppenheimer in 1947 to advise that it did

not appear hopeful to use natural uranium directly as an adequate source of fuel for atomic power. The reactivity of systems based on natural uranium is low; even the fraction of $235 \mathrm{U}$ which can be consumed without replenishing the fuel is small. Because of this the raw material requirements, if such reactors are to play an important part in power economy, are economically prohibitive. It is true that one could re-enrich this natural fuel, but the power expenditure involved in such isotope separation by any present methods makes this likewise prohibitive.

Although the General Advisory Committee to the Atomic Energy Commission discussed drafts of Oppenheimer's memorandum, it was not published for fear of undermining congressional support for the commission. Oppenheimer's ground for pessimism over natural uranium reactors has, as we know, proved exaggerated. Britain's Magnox reactors do 'burn up' some 0.5 per cent of the entire fuel since they fission about half 
the ${ }^{235} U$ and some of the plutonium they produce. Nevertheless reactors of this type are no longer built, precisely because they use so little of the fuel.

Considerable caution was also expressed at the first nuclear power session of the World Power Conference when the subject was included in this organization's Fuel Economy Conference at The Hague in 1947. Charles Thomas's calculation of the cost of nuclear electricity (nuclear 0.8 cents per Kwh, coal 0.65 cents) for the UN Atomic Energy Commission in 1946 was attacked by Con. Edison's research engineer, Ward F. Davidson and others. Both Sir John Cockcroft and L. Kowarski were cautious, the latter being decidedly caustic about the fast reactor. The tone was again cautious at the full session of the World Power Conference in 1951. Cockcroft said it was "like gazing into the crystal ball to ask us at this stage what operating and capital costs are going to be'. At the Atoms for Peace Conference of 1955 he was looking to this "second decade" (the 1970s) for the uranium/coal ratio to be raised by the breeder principle to at least a million to one.

It was in 1951 that work on the fast reactor had begun in the United Kingdom, stimulated by concern over uranium supplies. Eleven years later, the Dounreay fast reactor (DFR) began generating electricity. This $60 \mathrm{MW}(\mathrm{t})$ station was fueled with uranium, 75 per cent enriched ${ }^{235} \mathrm{U}$, not plutonium. It was run on full power for five years before being treated as a test bed for plutonium fuels. It has been succeeded by the prototype fast reactor (PFR) using mixed oxide fuel. By 1973 construction was completed and the following year saw operation at low power.

It is surely no accident that the potential world role of nuclear energy was being stressed in the United Kingdom from 1973 onwards based upon the promise of the fast reactor. Its high fuel utilization, claimed Sir John Hill in the magazine Atom, "will enable the vast reserves of very low-grade uranium to be utilized without significantly increasing the overall cost of electricity". World reserves of coal, he admitted, were enormous, but "we are consuming the most accessible and most convenient fuels (gas and oil) fastest and we are depleting most rapidly those reserves which are most conveniently situated geographically, economically and politically". Coal, though abundant, was expensive to mine and transport. Moreover the electricity industry needed flexibility to cope with shortages such as strikes and embargoes could create. Though improvements in UK coal production were impressive, the industry remained in Sir John Hill's words " essentially a labour intensive industry despite increasing use of machinery and, if the men employed are to maintain a standard of living compatible with the task they are being asked to undertake, the labour costs of the industry will rise and this must be reflected in the cost". The context of these words was provided by the coal price rise of 40 per cent over eighteen months in 1969-70 and the picketing of power stations by mineworkers in 1972 . More was to follow - the 140 per cent price rise of coal in 1975, the 400 per cent price rise of oil in 1973-74 and the miners' strike of 1974 which involved a four-month dispute in the industry.

\section{Conclusion}

Statistics on fuel reserves do not constitute cold hard facts, they are judgements about the probable outcome of a series of events in space and time. One might even claim tha they do not so much form government policy as result from such policy. Since the introduction of oil-fired power stations in the 1950s the policy of building a multi-fuel base to electricity generation with nuclear base-load has been followed by both political parties. Whereas governments have in the past given some protection to coal against oil there has been from 1955 onwards a consistent policy of favouring nuclear power, a policy shared by the Central Electricity Generating Board whose aim it is to increase dependence upon nuclear-generated electricity for base load, and thus to diminish the impact of higher coal prices and the threat posed by the withdrawal of labour in the coal industry. When the all-party Commons Committee on Energy delivered its report in February 1981, a Daily Telegraph editorial described the recommended "cut-back in nuclear power station construction" as "naive, petty-minded, and ill-informed". The editorial continued:

It is no doubt bad luck for its authors that the report appeared just as an indefinite national coal strike was threatened. But we, on the other hand, should be thankful for the timing. It enables us to see how absurd it would be not to invest massively in nuclear power at a time when coal supplies are under constant threat, and, more important still, when the Russians are reaching out greedy claws towards the Middle East oil wells.

Clearly the formulation of energy policy is a highly political process. The decisions reached can affect the estimates of reserves themselves. Investment in machinery, prospecting, methods of combustion and of fission, all influence what proportion of the total resource may be considered as economically extractable reserves. Thus fluidized-bed-combustion can be achieved profitably with low grade coal of ash content up to 55 per cent instead of the maximum 30 per cent for conventional combustion, thus bringing high-ash coal deposits into the reserves. Similarly highsulphur coals whose combustion causes acid rain can be burnt without liberation of sulphur dioxide in the fluidized bed. Uranium reserves, which at present are trivial by comparison with coal, are increased in terms of their energy yield some sixty-fold with the fast reactor. This, in turn, will allow lower-grade ores to be brought from the resource category and
FOR an excellent critical discussion of resource nomenclature the reader is referred to G. B. Fettweiss, World Coal Resources: Methods of Assessment and Results (Elsevier, Amsterdam, 1979). Also invaluable are: The Royal Society's submission to the Commission on Energy and the Environment, Environmental Aspects of Increased Coal Usage in the U.K. (February 1980) and the WATT Committee on Energy, Assessment of Energy Resources, Committee Report 9 (1981) and the report of the Commission on Energy and the Environment, Coal and the Environment (1982). The proceedings of the November 1981 British Nuclear Energy Society conference on the fast reactor fiuel cycle should be published soon. There the "reasonably assured resources" of uranium are given as $\mathbf{2 . 6}$ million tonnes.

added to the economically exploitable reserves. There is a sense, then, in which, as Clarke has remarked, an investment decision which significantly favours one energy industry at the expense of the others, is likely to be self-fulfilling, and may thus prove to have been economically and financially correct.

The claimed potentials of both coal and spent uranium fuel reserves raise sensitive issues - fears of increased seismic activity, water table changes and water contamination, in the case of coal mining; concerns about reprocessing and long-term storage, and doubts about the commercial performance of the fast reactor, in the case of spent uranium fuel. If the Coal Board's estimate of $45 \times 10^{9}$ tonnes looks like a "giant extrapolation" to quote a Nature editorial, how much better are the claims made on behalf of spent uranium fuel? True it has not to be mined, but it will have to be reprocessed many times before even half its energy content has been liberated.

This analysis of energy resource claims does not suggest intentional rivalry by the Atomic Energy Authority and the National Coal Board. Their presentation about the same time was fortuitous. That they both represent responses at the political level in the campaign for government support seems evident. Also clear from this analysis is the fact that the modern distinction between resources and reserves, though dating from 1949, is still in the process of winning general acceptance. Reluctance to adopt it might well be due not only to tradition but also to the tendency which strict definitions of economic reserves have to belittle the long-term potential of an industry's resources. If decision-makers have some appreciation of the factors involved in the process of converting resources into reserves then the application of this fundamental distinction of nomenclature will be more consistently adopted.

I acknowledge the assistance of $\mathrm{Mr} \mathbf{A}$. Michael Clarke, Dr Leslie Grainger and Professor E. H. Francis; Mr Keith Bowes kindly commented on an earlier draft of the section of the paper given to nuclear energy. The extract from Oppenheimer's memorandum to the AEC Advisory Committee is cited with the permission of the US Department of Energy. 